\title{
KARAKTERISTIK SIFAT OPTIK DAN SIFAT LISTRIK LAPISAN TIPIS KARBON AMORF TERHIDROGENASI (a-C:H) YANG DIPABRIKASI DENGAN TEKNIK RF-PECVD
}

\author{
${ }^{1 *}$ Muh Saleh, ${ }^{2)}$ Budhi Priyanto, ${ }^{3)}$ Yoyok Cahyono, ${ }^{4)}$ Darminto \\ ${ }^{1)}$ Jurusan Fisika, Fakultas Matematika dan Ilmu Pengetahuan Alam, Universitas Negeri \\ Makassar, \\ ${ }^{2)}$ Jurusan Teknik Elektro, Fakultas Teknik, Universitas Muhammadiyah Malang, \\ ${ }^{3,4)}$ Advanced Materials Research Group, Departemen Fisika, Fakultas Ilmu Alam, Institut \\ Teknologi Sepuluh Nopember Surabaya, \\ ${ }^{*}$ Corresponding Author: m.saleh79@unm.ac.id
}

\begin{abstract}
Abstrak. Lapisan tipis karbon amorf terhidrogenasi (a-C:H) telah berhasil ditumbuhkan di atas substrat kaca ITO dengan teknik Radio Frequency - Plasma Enhanced Chemical Vapor Deposition (RF-PECVD) pada frekuensi standar 13,56 MHz. Efek variasi parameter laju aliran gas metana $\left(\mathrm{CH}_{4}\right)$ murni dari 40 sampai $100 \mathrm{sccm}$ terhadap sifat optik dan sifat listrik lapisan a-C:H diselidiki dalam penelitian ini. Parameter temperatur substrat, tekanan deposisi, daya RF, dan waktu deposisi dibuat konstan pada nilai $100{ }^{\circ} \mathrm{C}, 450 \mathrm{mTorr}, 15 \mathrm{~W}$ dan 120 menit. Jenis fase, ketebalan, celah pita energi dan konduktivitas listrik lapisan a-C:H masing-masing dikarakterisasi dengan Difraksi Sinar - X (XRD), Scanning Electron Microscopy (SEM), spektroskopi UV-Vis dan probe 4-titik (FourPoint Probe). Hasil karakterisasi dengan XRD menunjukkan bahwa struktur lapisan a-C:H yang diperoleh berfase amorf. Peningkatan laju aliran metana dari 40 sampai 100 sccm dengan selang 20 sccm telah meningkatkan ketebalan lapisan tipis a-C:H pada nilai $641,5-1256 \mathrm{~nm}$ dengan laju deposisi 5,43 - 10,47 $\mathrm{nm} /$ menit serta peningkatan konduktivitas listrik lapisan pada rentang nilai $6,90 \times 10^{-2}-7,43 \times 10^{-2} \mathrm{~S} / \mathrm{cm}$ yang berakibat pada penurunan celah pita energi lapisan dari $2,55 \mathrm{eV}$ menjadi 2,00 eV dengan meningkatnya laju aliran metana.
\end{abstract}

Kata Kunci : Deposisi, RF-PECVD, Lapisan tipis a-C:H, Laju Aliran Gas Metana.

Abstract. A thin films of hydrogenated amorphous carbon (a-C:H) was successfully grown on the ITO glass substrate with the Radio Frequency - Plasma Enhanced Chemical Vapor Deposition (RFPECVD) technique at a standard frequency of $13.56 \mathrm{MHz}$. The effect of the variation of pure methane $\left(\mathrm{CH}_{4}\right)$ flow rate parameters of 40 to $100 \mathrm{sccm}$ on the optical properties and electrical properties of a-C:H thin films were investigated in this study. The parameters of substrate temperature, deposition pressure, $R F$ power, and deposition time are kept constant at $100^{\circ} \mathrm{C}, 450$ mTorr, $15 \mathrm{~W}$ and 120 minutes. Phase type, thickness, band gap energy and electrical conductivity of a-C:H thin films are each characterized by X-Ray Diffraction (XRD), Scanning Electron Microscopy (SEM), UV-Vis spectroscopy and 4-point probes. The results of XRD characterization showed that the a-C:H thin layer structure obtained was amorphous. Increased methane flow rates from 40 to $100 \mathrm{sccm}$ with an interval has increased the thickness of the a-C:H thin films at values $641.5-1256 \mathrm{~nm}$ and the deposition rate of $5.43-10.47 \mathrm{~nm} / \mathrm{min}$. as well as an increase in the electrical conductivity in the range of values $6.90 \times 10^{-2}-7.43 \times 10^{-2} \mathrm{~S} / \mathrm{cm}$ which results in a decrease of the band gap energy from $2.55 \mathrm{eV}$ to $2.00 \mathrm{eV}$ with increasing methane flow rate.

Keywords : Deposition, RF-PECVD, a-C:H Thin Films, Methane flow rate.

\section{PENDAHULUAN}

Saat ini, berbagai material untuk lapisan tipis dengan sifat-sifat yang fleksibel dan terkontrol untuk aplikasi yang diinginkan telah menjadi topik yang menarik perhatian dalam teknologi rekayasa material. Salah satunya adalah lapisan tipis karbon amorf yang menunjukkkan sifat listrik, mekanik, kimia, dan optik yang unik dan dapat disesuaikan atau divariasikan berada antara sifat intan dan grafit alami.
Istilah a-C digunakan untuk memasukkan bentuk karbon non-kristal yang mengandung hidrogen (terhidrogenasi). Berdasarkan pada konten atom $\mathrm{H}$, lapisan karbon amorf dapat diklasifikasikan menjadi dua kelompok, karbon amorf bebas-H (a-C) dan karbon amorf terhidrogenasi (a-C:H) (Raza, 2012). Fleksibilitas material ini berasal dari konfigurasi ikatan kimianya yang dapat berbentuk hibridisasi $\mathrm{sp}^{3}$, 
$\mathrm{sp}^{2}$, atau $\mathrm{sp}^{1}$ (J Robertson, 2002). Diagram fase terner unsur karbon ditunjukkan pada Gambar 1.

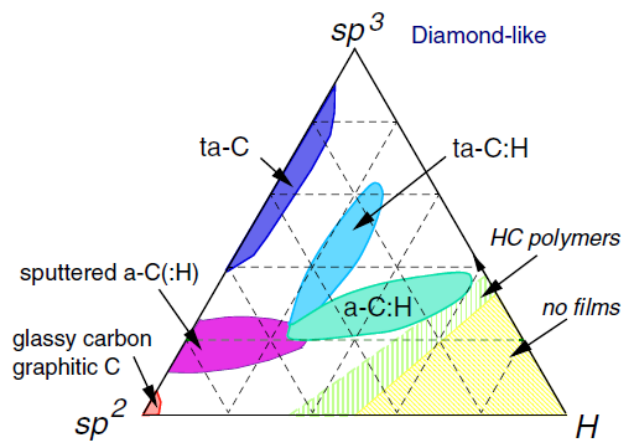

Gambar 1. Diagram Fase Terner Unsur Karbon (John Robertson, 2011).

Lapisan a-C:H mengandung campuran ikatan hibrid trigonal tipe grafit $\mathrm{sp}^{2}$ (Graphitelike) dan ikatan hibrid tetrahedral tipe intan $\mathrm{sp}^{3}$ (Diamond-like) (Kim et al., 2003; Nelson et al., 2014; Podder et al., 2005; J. Robertson, 1995; Toro et al., 2017). Kemampuan untuk mengontrol rasio ikatan $\mathrm{sp}^{3}$ ke $\mathrm{sp}^{2}$ melalui kondisi penumbuhannya, memungkinkan pengembangan lapisan tipis a-C:H yang memiliki sifat mekanis, listrik, dan optik yang sangat berbeda. Selain hibridisasi ikatan, parameter kedua, yaitu konten hidrogen, memainkan peran penting dalam menentukan sifat lapisan tipis ini (Awang, 2008; Grill, 1999; Mahtani, 2010; Xiao et al., 2017).

Kombinasi dari dua sifat (intan dan grafit) yang dimiliki oleh lapisan tipis a-C:H dapat menghasilkan sifat baru yang lebih unik dan variatif, antara lain: tingkat kekerasan yang relatif tinggi, koefisien gesekan yang rendah, stabilitas termal yang tinggi, transparansi optik yang baik, transmitansi yang tinggi terhadap radiasi inframerah hingga ultraviolet, ketahanan terhadap aus, resistivitas listrik yang tinggi, celah pita energi (energy gap) yang lebar yang berkisar antara $0-6 \mathrm{eV}$ dan konduktivitas termal yang baik (Manage, 1998; Tomasella et al., 2001, 2004; Toro et al., 2017).

Dari segi sifat optik, lapisan tipis a-C:H dengan nilai rata-rata transmitansi optik $90 \%$ pada panjang gelombang $350-900 \mathrm{~nm}$ dan rentang celah pita energi 2,89-3,72 eV menjadi material yang menjanjikan untuk aplikasi lapisan anti refleksi atau lapisan jendela pada sel surya serta lapisan aktif pada LED (Xiao et al., 2017). Penelitian yang berhasil menunjukkan bahwa lapisan tipis a-C:H dengan celah energi $\sim 2,2 \mathrm{eV}$ dan indeks refraksi $\sim 1,65$ menjadikan material ini layak sebagai lapisan anti refleksi pada aplikasi sel surya (Das \& Banerjee, 2015).

Lapisan tipis a-C:H dapat dipabrikasi dengan berbagai teknik, antara lain: Plasma Enhanched Chemical Vapor Deposition (PECVD), Pulsed Laser Deposition, Ion Beam Assisted Deposition, Sputtering, and Filtered Cathodic Vacuum Arc (Das \& Banerjee, 2015; Tomasella et al., 2001). PECVD menggunakan plasma RF dalam gas hidrokarbon, adalah teknik yang paling cocok dan banyak digunakan, yang memungkinkan pertumbuhan lapisan tipis a-C:H pada berbagai substrat, dan dalam kisaran suhu yang luas, terutama pada suhu ruang. Lebih dari itu, PECVD juga menghasilkan deposisi yang seragam pada area yang luas (Möller et al., 1995; Nelson et al., 2014; Podder et al., 2005).

Pengaruh parameter deposisi seperti suhu, tekanan, daya RF, dan rasio laju aliran gas pada sifat lapisan tipis a-C:H sangat penting. Oleh karena itu, memungkinkan untuk memperoleh film a-C:H dengan berbagai sifat dengan memvariasikan parameter deposisi dalam proses pertumbuhan.

\section{METODE}

Penumbuhan sampel lapisan tipis a-C:H dalam penelitian ini menggunakan sistem reaktor RF-PECVD plat paralel Laboratorium Energi Institut Teknologi Sepuluh Nopember (ITS) Surabaya, yang beroperasi pada frekuensi 13,56 MHz dengan metana murni $\left(\mathrm{CH}_{4}\right)$ sebagai gas utama di atas substrat gelas berlapis Indium Tin Oxide (ITO) berukuran 10x10 $\mathrm{cm}^{2}$. Sebelum proses deposisi, substrat gelas terlebih dahulu dibersihkan di dalam bak ultrasonic cleaner menggunakan etanol dan diwater secara bergantian masing-masing selama 10 menit yang bertujuan untuk menghilangkan lapisan oksida 
resistif pada permukaan gelas substrat, selanjutnya dikeringkan. Skema dan sistem chamber reaktor RF-PECVD yang digunakan dalam penelitian ini ditunjukkan pada Gambar 2.

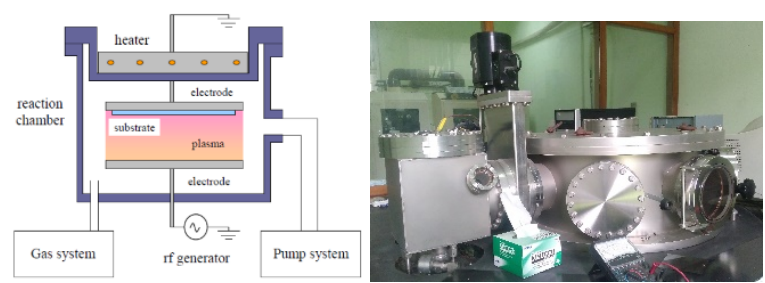

Gambar 2. Skema dan Sistem Chamber Raktor RF-PECVD Lab Energi ITS Surabaya

Satu set sampel lapisan dideposisi dengan variasi laju aliran gas $\mathrm{CH}_{4}$ murni dari $40-100$ sccm untuk menghasilkan ketebalan yang berbeda. Selama proses deposisi, parameterparameter lain seperti: daya RF, tekanan deposisi, suhu substrat, dan durasi waktu deposisi dijaga konstan pada nilai masing-masing: $15 \mathrm{~W}, 450$ mTorr, $100{ }^{\circ} \mathrm{C}$, dan 120 menit.

Pengujian sampel dengan difraksi sinar-X (XRD) dilakukan di Laboratorium Teknik Material ITS dengan menggunakan difraktometer tipe Philips X'Pert MPD (Multi Purpose Diffractometer) dengan radiasi $\mathrm{Cu}-\mathrm{K} \alpha$, tegangan $40 \mathrm{kV}$ dan arus $30 \mathrm{~mA}$ dengan target logam $\mathrm{Cu}$ $(\lambda=1,54056 \AA)$. Data difraktogram XRD yang dihasilkan selanjutnya dianalisis secara kualitatif untuk mengidentifikasi jenis fase sampel lapisan hasil deposisi dengan bantuan perangkat lunak Match!2.

Ketebalan sampel lapisan diukur dengan Scanning Electron Microscopy (SEM) dengan arah melintang (Cross - Section) di Laboratorium Teknik Material ITS. Untuk karakterisasi sifat optik sampel lapisan dilakukan di Laboratorium Kimia ITS menggunakan instrumen UV-Vis GENESYS 10S Spectrophotometer dengan rentang panjang gelombang $200,0 \mathrm{~nm}-800,0 \mathrm{~nm}$ pada interval $1,0 \mathrm{~nm}$. Untuk keperluan karakterisasi sifat listrik sampel lapisan, dilakukan di Laboratorium Fisika Elektronika dan Instrumentasi FMIPA UNM dengan metode probe 4-titik (Four - Point Probe) untuk menentukan resistivitas dan konduktivitas listrik sampel lapisan a-C:H. Skema pengukuran ini ditunjukkan pada Gambar 3.

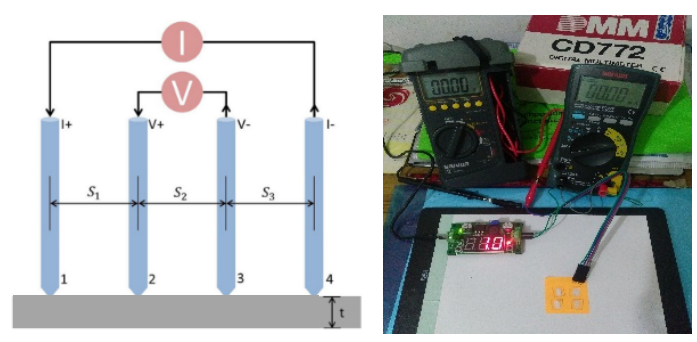

Gambar 3. Skema Pengukuran Konduktivitas Listrik lapisan Tipis dengan Probe 4-titik.

\section{HASIL DAN PEMBAHASAN}

Gambar 4 menunjukkan difraktogram hasil XRD untuk keempat lapisan a-C:H yang diperoleh yang disertai hasil analisis search and match dengan software Match!2.

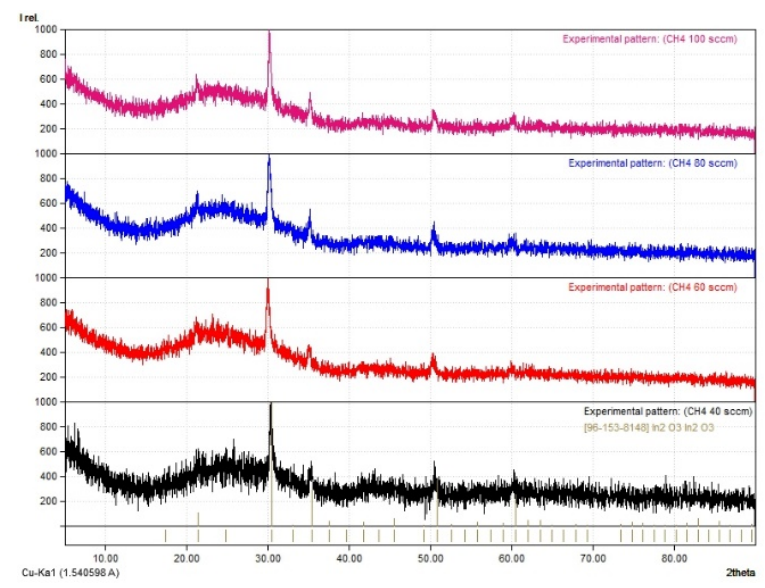

Gambar 4. Difraktogram XRD Sampel Lapisan a-C:H

Secara umum, terlihat bahwa keempat sampel lapisan a-C:H yang terbentuk menunjukkan fase amorf di mana puncak difraksi yang menunjukkan fase kristal tidak terbentuk. Adapun puncak difraksi yang teridentifikasi dalam difraktogram pada sudut-sudut $2 \theta$ sekitar $21^{\circ}, 30^{\circ}, 35^{\circ}, 50^{\circ}$, dan $60^{\circ}$ menunjukkan puncak-puncak fase kristal dari 
indium oksida $\left(\operatorname{In}_{2} \mathrm{O}_{3}\right)$ pada lapisan konduktif substrat (ITO).

Hasil identifikasi ini diperkuat oleh hasil search and match dengan perangkat lunak Match!2 dan dari difraktogram struktur lapisan ITO yang ditumbuhkan pada substrat kaca yang menunjukkan puncak-puncak spectra $\operatorname{In}_{2} \mathrm{O}_{3}$. Dengan demikian, secara kualitatif telah menunjukkan bahwa keempat sampel lapisan a-C:H telah berhasil ditumbuhkan dengan struktur lapisan berfase amorf.

Lapisan karbon amorf biasanya menunjukkan morfologi yang halus, khususnya pada substrat konduktif, SEM tidak banyak memberikan informasi mengenai struktur lapisan yang diuji. Bahkan, karena konduktansi listrik dari lapisan karbon amorf relatif rendah dapat mendistorsi hasil penggambaran SEM. Akan tetapi gambaran SEM dalam orientasi vertikal (cross-section) cukup akurat digunakan untuk menentukan ketebalan lapisan a-C:H (Chu \& Li, 2006). Gambar 5 menunjukkan mikrograf SEM dalam arah vertikal untuk keempat sampel lapisan a-C:H masing untuk laju aliran gas metana 40, 60, 80 dan $100 \mathrm{sccm}$.
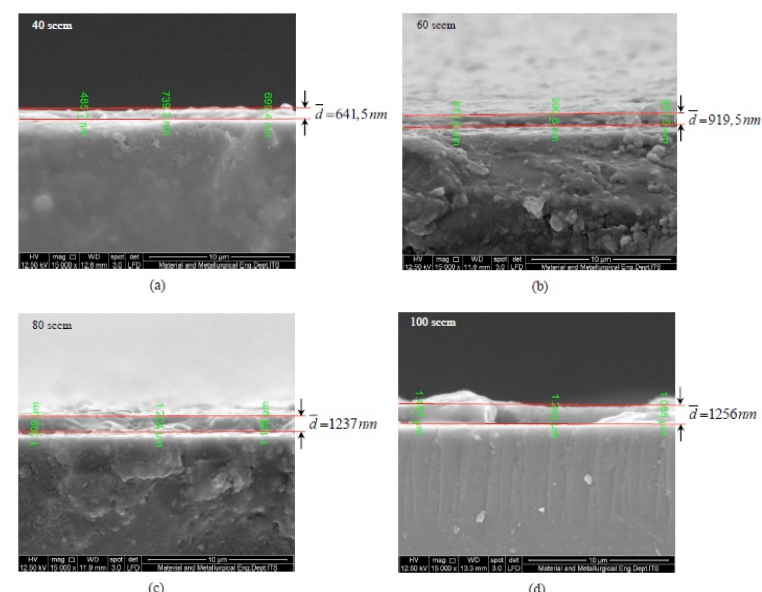

Gambar 5. Mikrograf SEM arah vertikal pada keempat sampel lapisan a-C:H.

Berdasarkan mikrograf SEM tampak samping dari keempat sampel pada Gambar 5, terlihat adanya batas yang jelas antara lapisan dengan substrat kaca yang menjadi indikator bahwa lapisan a-C:H telah berhasil ditumbuhkan dengan ketebalan rata-rata setiap lapisan masingmasing 641,5 nm, 919,5 nm, $1237 \mathrm{~nm}$ dan 1256 nm yang sebanding dengan peningkatan laju aliran metana.

Berdasarkan nilai ketebalan lapisan a-C:H untuk setiap nilai laju aliran metana yang diperoleh, maka laju deposisi lapisan a-C:H yang diperoleh dalam penelitian ini dapat ditentukan. Gambar 6 menunjukkan grafik hubungan antara laju aliran metana dengan ketebalan dan laju deposisi lapisan a-C:H.

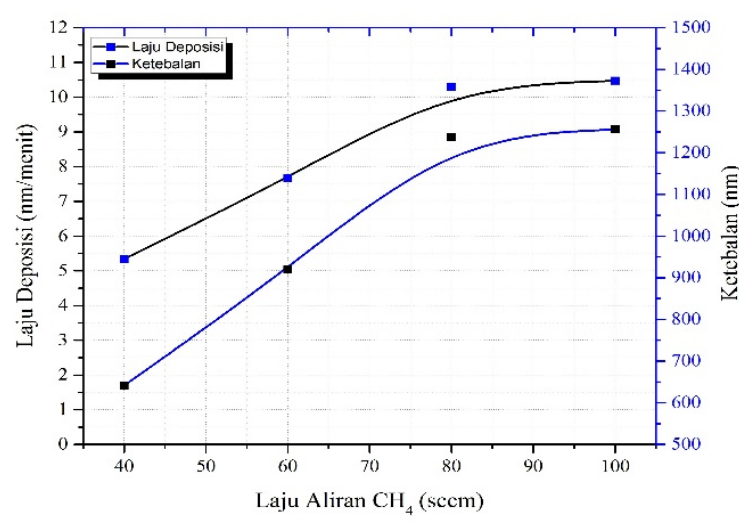

Gambar 6. Grafik ketebalan dan laju deposisi sampel lapisan a-C:H sebagai fungsi laju aliran metana.

Gambar 6 menunjukkan bahwa keduanya, ketebalan dan laju deposisi sampel lapisan a-C:H yang berhasil ditumbuhkan meningkat sebagai fungsi laju aliran metana. Peningkatan laju aliran metana berarti semakin besarnya volume metana per satuan waktu (dalam satuan sccm) yang terdisosiasi menjadi spesies reaktif berupa molekul hidrokarbon dan ion-ion membentuk yang terpapar di atas permukaan substrat dan peningkatan generasi jaringan adsorpsi pada permukaan lapisan oleh bombandir ion-ion bernenergi tinggi. Dengan demikian, ketebalan dan laju deposisi lapisan a-C:H menjadi meningkat (Awang, 2008). Laju aliran gas juga menentukan lamanya molekul gas metana berada dalam ruang reaksi untuk diurai menjadi molekulmolekul yang lebih sederhana. Pemberian laju 
aliran metana dari 40-100 sccm telah menghasilkan peningkatan nilai laju deposisi dan ketebalan lapisan a-C:H yang berhasil ditumbuhkan. Hal ini dapat pula diakibatkan oleh pemberian daya RF sebagai sumber energi pengurai masih efektif mendisosiasi molekulmolekul metana khususnya pada rentang laju aliran metana 40-80 sccm yang menunjukkan derajat kemiringan kurva yang besar dibanding pada rentang laju aliran metana 80-100 sccm. Secara umum, peningkatan laju deposisi ini merupakan indikator terjadinya disosiasi molekul metana oleh akibat bombardir ion-ion berenergi tinggi dan peningkatan jaringan adsorpsi pada permukaan (Usman \& Winata, 2009).

Jenis transisi optik dan celah pita energi dalam semikonduktor dapat ditentukan berdasarkan koefisien absorpsi sebagai fungsi dari energi foton untuk material amorf menggunakan persamaan Tauc (Pimpabute et al., 2011):

$$
(\alpha h v)^{1 / 2}=B\left(h v-E_{g}\right)
$$

di mana $B$ adalah konstanta absorpsi, $h v=E$ adalah energi foton, $E_{g}$ adalah celah pita energi dan $\alpha$ adalah koefisien absorpsi yang diperoleh dengan menggunakan persamaan (Mahtani, 2010):

$$
\alpha(\lambda)=-\frac{1}{d} \ln T(\lambda)
$$

di mana $d$ adalah ketebalan lapisan a-C:H yang diperoleh dari hasil foto SEM dan $T(\lambda)$ adalah koefisien transmitansi sampel sebagai fungsi panjang gelombang yang diperoleh dari hasil karakterisasi UV-Vis.

Celah pita energi atau energi gap, $E_{g}$, secara umum menyatakan selisih energi antara puncak pita valensi dan dasar pita konduksi di mana tidak terdapat keadaan elektron bebas. Untuk kasus a-C:H, energi gap mengacu pada pemisahan antara keadaan terisi $\pi$ dan keadaan kosong $\pi^{*}$ seperti yang telah ditunjukkan pada Gambar 7 .

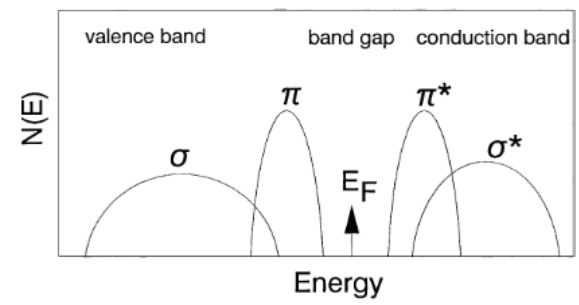

Gambar 7. Skema rapat keadaan bahan karbon amorf (Robertson, 2002)

Telah diterima secara umum bahwa lapisan a-C:H mengandung atom-atom terhibridisasi $\mathrm{sp}^{3}$ dan $\mathrm{sp}^{2}$ (J. Robertson, 1995). Jaringan ikatan karbon $\mathrm{sp}^{2}$ cenderung berkumpul untuk membentuk cluster yang tertanam dalam matriks ikatan $\mathrm{sp}^{3}$. Ikatan $\sigma$ jaringan $\mathrm{sp}^{3}$ memiliki energi gap yang lebar hingga mencapai $6 \mathrm{eV}$ dan ikatan $\pi$ jaringan $\mathrm{sp}^{2}$ memiliki energi gap yang lebih sempit. Telah dilaporkan pada penelitian sebelumnya bahwa energi gap dari semua jenis lapisan a-C:H bervariasi hampir secara linier dengan kandungan karbon $\mathrm{sp}^{2}$, di mana energi gap menurun dengan peningkatan kandungan karbon $\mathrm{sp}^{2}$ (Heitz et al., 1998; John Robertson, 2011). Kurva Tauc (Tauc-plot) untuk keempat sampel lapisan a-C:H dalam penelitian ini ditunjukkan pada Gambar 9.

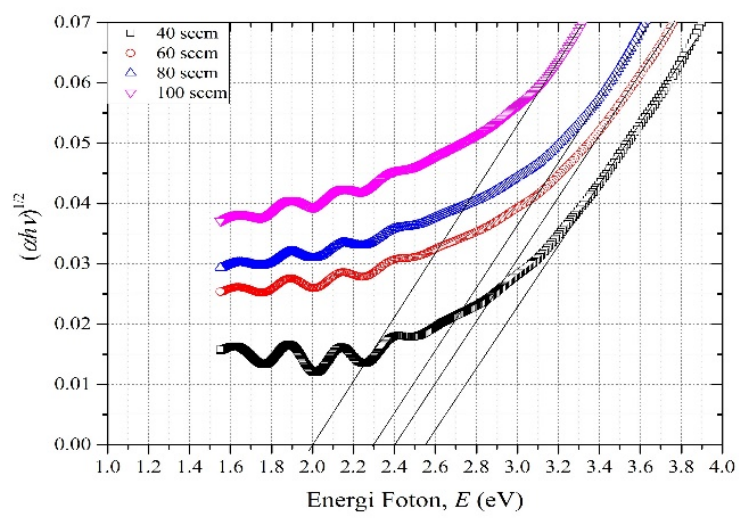

Gambar 9. Kurva Tauc untuk keempat sampel lapisan a-C:H. 
Dalam relasi Tauc, $\alpha$ adalah koefisien absorpsi yang ditentukan oleh ketebalan dan transmitansi lapisan a-C:H sebagai fungsi panjang gelombang sedangkan $E$ adalah energi foton radiasi UV-Vis. Nilai $(\alpha h v)^{1 / 2}$ pada kurva Tauc menunjukkan besarnya absorpsi energi radiasi $\mathrm{UV}-\mathrm{Vis}$ tiap satuan ketebalan (dalam $\mathrm{eV} / \mathrm{nm}$ ). Daerah absorpsi ini menunjukkan dimulainya transisi elektron dari titik maksimum orbital molekul terisi paling tinggi (Highet Occupied Molecule Orbital, HOMO) pada pita valensi ke titik minimum orbital molekul kosong paling rendah (Lowest Unoccupied Molecule Orbital, LUMO) pada pita konduksi. Untuk kasus karbon amorf, HOMO adalah orbital ikatan $\pi$ dan LUMO adalah orbital ikatan $\pi^{*}$ (Awang, 2008; J Robertson, 2002).

Kurva Tauc pada Gambar 9, menunjukkan peningkatan nilai absorpsi energi per satuan ketebalan lapisan sebagai fungsi energi foton. Titik di mana mulai terjadinya peningkatan secara linier menunjukkan titik ambang mulainya transisi elektronik dalam struktur lapisan a-C:H. Ekstrapolasi daerah absorpsi linier pada masingmasing kurva, maka perpotongan garis dengan sumbu energi foton di mana nilai $(\alpha h v)^{1 / 2}=0$ menunjukkan estimasi nilai celah pita energi atau energi gap setiap sampel (Hassanien \& Akl, 2015).

Gambar 9 juga menunjukkan penurunan nilai energi gap lapisan a-C:H dengan meningkatnya laju aliran metana. Penurunan nilai energi gap ini dapat disebabkan oleh peningkatan kandungan ikatan $\mathrm{sp}^{2}$ dalam lapisan dengan meningkatnya laju aliran metana. Penurunan lebar pita $\pi-\pi^{*}$ sangat erat kaitannya dengan ukuran unit struktural yang mengandung jaringan $\mathrm{sp}^{2}$, sehingga dapat dikatakan bahwa penurunan energi gap menunjukkan bahwa terjadi peningkatan ukuran cluster $\mathrm{sp}^{2}$ dan juga energi gap bergantung pada konfigurasi jaringan $\mathrm{sp}^{2}$, tidak dipengaruhi oleh kandungan ikatan $\mathrm{sp}^{3}$ (J Robertson, 2002). Namun, kandungan hidrogen juga telah dilaporkan memiliki pengaruh signifikan terhadap energi gap dalam lapisan a-C:H, di mana kandungan hidrogen yang lebih tinggi mengakibatkan pelebaran atau peningkatan energi gap (Tomasella et al., 2001).

Secara umum, resistivitas dan konduktivitas listrik suatu bahan merupakan kuantitas makroskopik yang menyatakan tingkah laku pembawa muatan yang bertransisi dari pita valensi yang terisi penuh ke pita konduksi yang kosong melintasi celah pita energi tertentu, dalam kasus bahan karbon amorf, dari pita $\pi$ yang terisi penuh ke pita $\pi^{*}$ yang kosong. Teori tentang konduktivitas lapisan karbon amorf telah lama dikaji namun belum diperoleh teori yang komprehensif untuk menjelaskan tingkah laku pembawa muatan, khususnya mobilitas di daerah tepi. Namun demikian, telah diketahui dengan pasti bahwa mobilitas pembawa muatan bahan semikonduktor pada umumnya sangat bergantung pada posisi Fermi (Fermi-level) dalam struktur pita energinya (Sze, 2002).

Hasil pengukuran resistivitas keempat sampel lapisan a-C:H dengan menggunakan metode empat titik (4-point probe) diperoleh nilai arus dan tegangan yang terukur, resistivitas dan konduktivitas listrik lapisan tipis a-C:H dapat ditentukan dengan (Li et al., 2016):

$$
\sigma=\frac{1}{\rho} \text { dengan } \rho=4 \pi S \frac{V}{I}
$$

di mana $S$ adalah jarak antar probe. Persamaan (3) berlaku untuk rasio ketebalan lapisan tipis dengan jarak antar probe, $(t / S)<0,5$. Grafik konduktivitas 
listrik lapisan a-C:H sebagai fungsi laju aliran metana ditunjukkan pada Gambar 10.

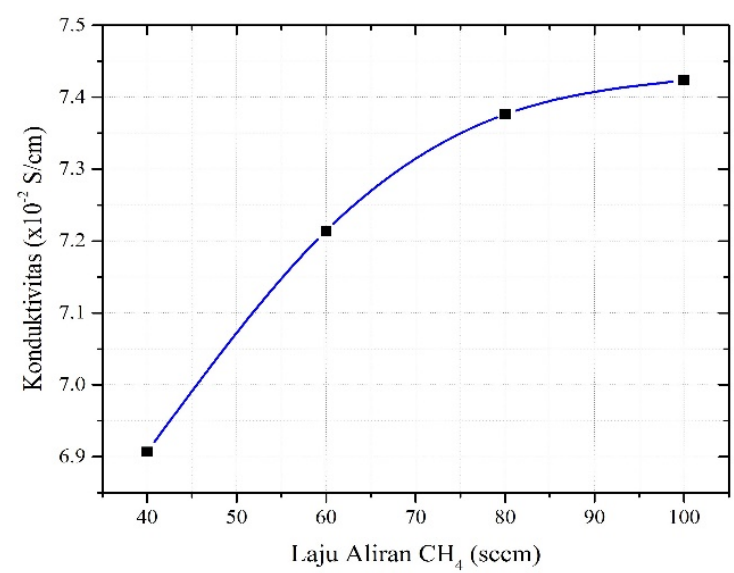

Gambar 10. Grafik konduktivitas listrik keempat sampel lapisan a-C:H sebagai fungsi laju aliran metana.

Terlihat bahwa konduktivitas listrik keempat sampel lapisan a-C:H meningkat dari $6,90 \times 10^{-2}-7,43 \times 10^{-2} \mathrm{~S} / \mathrm{cm}$ dengan peningkatan laju aliran metana dari $40-100 \mathrm{sccm}$. Hal ini menunjukkan bahwa konduktivitas listrik lapisan a-C:H yang diperoleh dalam penelitian ini dipengaruhi oleh laju aliran metana ataupun ketebalan lapisan. Secara umum, nilai konduktivitas listrik yang diperoleh dalam penelitian ini berada dalam rentang nilai konduktivitas listrik bahan semikonduktor yang berkisar $10^{-8}-10^{3} \mathrm{~S} / \mathrm{cm}$ (Sze, 2002).

Pada hasil dan pembahasan sebelumnya telah ditemukan bahwa peningkatan laju aliran metana dari 40 - $100 \mathrm{sccm}$ yang juga diiringi oleh peningkatan ketebalan lapisan dari 641,5 - 1256 nm menyebabkan menurunnya nilai energi gap dari 2,55 - 2,00 eV. Dengan demikian, perubahan nilai konduktivitas listrik lapisan a-C:H sangat terkait dengan perubahan nilai energi gap yang diperoleh, di mana konduktivitas listrik meningkat dengan penurunan energi gap lapisan a-C:H. Hal ini dapat dipahami bahwa dengan energi gap yang lebih kecil dalam lapisan a-C:H akan menyebabkan mobilitas pembawa muatan menjadi lebih besar untuk bertransisi dari keadaan $\pi$ yang terisi penuh ke keadaan $\pi^{*}$ yang kosong. Konduktivitas listrik keempat sampel lapisan a-C:H yang diperoleh dalam penelitian ini menunjukkan nilai relatif besar yang dapat disebabkan oleh lapisan substrat yang digunakan dalam penumbuhan lapisan bersifat konduktif.

\section{KESIMPULAN}

Berdasarkan hasil analisis yang diperoleh dalam penelitian ini, maka dapat ditarik beberapa kesimpulan sebagai berikut.

1. Hasil karakterisasi XRD dan SEM telah menunjukkan bahwa lapisan a-C:H telah berhasil ditumbuhkan di atas substrat kaca ITO dengan teknik RF-PECVD.

2. Peningkatan laju aliran metana sebagai gas utama dari $40-100 \mathrm{sccm}$ telah meningkatkan ketebalan lapisan dari 641,5 - $1256 \mathrm{~nm}$ dan laju deposisi lapisan a-C:H dari 5,34-10,47 $\mathrm{nm} / \mathrm{menit}$.

3. Peningkatan laju aliran gas metana dari $40-$ $100 \mathrm{sccm}$ yang disertai dengan peningkatan ketebalan lapisan telah menurunkan energi gap lapisan a-C:H dari nilai 2,55 eV menjadi $2,00 \mathrm{eV}$.

4. Peningkatan laju aliran gas metana dari 40 $100 \mathrm{sccm}$ yang disertai dengan penurunan energi gap lapisan telah meningkatkan konduktivitas listrik lapisan a-C:H dari nilai $6,90 \mathrm{~S} / \mathrm{cm}$ menjadi $7,43 \mathrm{~S} / \mathrm{cm}$.

\section{DAFTAR RUJUKAN}

Awang, R. B. (2008). PECVD Hydrogenated Amorphous Carbon Films: Growth and Characterization. University of Malaya.

Chu, P. K., \& Li, L. (2006). Characterization of Amorphous and Nanocrystalline Carbon Films. Materials Chemistry and Physics, 96(2-3), 253-277.

Das, D., \& Banerjee, A. (2015). Anti-Reflection Coatings for Silicon Solar Cells From 
Hydrogenated Diamond-Like Carbon. Applied Surface Science, 345, 204-215.

Grill, A. (1999). Diamond-Like Carbon: State of the Art. Diamond and Related Materials, $8(2-5), 428-434$.

Hassanien, A. S., \& Akl, A. A. (2015). Influence of composition on optical and dispersion parameters of thermally evaporated noncrystalline Cd50S50-xSex thin films. Journal of Alloys and Compounds, 648, 280-290.

Heitz, T., Drévillon, B., Godet, C., \& Bourée, J. E. (1998). Quantitative Study of C-H Bonding in Polymerlike Amorphous Carbon Films using In Situ Infrared Ellipsometry. Physical Review B, 58(20), 13957-13973.

Kim, J., Lee, K., Kim, K., Sugimura, H., Takai, O., $\mathrm{Wu}, \mathrm{Y} ., \quad \&$ Inoue, Y. (2003). Characteristics and High WaterRepellency of a-C:H Films Deposited by r.f. PECVD. Surface and Coatings Technology, 162(2-3), 135-139.

Li, M.-Y., Yang, M., Vargas, E., Neff, K., Vanli, A., \& Liang, R. (2016). Analysis of variance on thickness and electrical conductivity measurements of carbon nanotube thin films. Measurement Science and Technology, 27(9), 095004.

Mahtani, P. (2010). Optical and Structural Characterization of Amorphous Carbon Films. University of Toronto.

Manage, D. P. (1998). Structural and Optical Characterization of Hydrogenated Amorphous Carbon Thin Films. University of Toronto.

Möller, W., Fukarek, W., Lange, K., Keudell, A. von, \& Jacob, W. (1995). Mechanisms of the Deposition of Hydrogenated Carbon Films. Japanese Journal of Applied Physics, 34(Part 1, No. 4B), 2163-2171.

Nelson, N., Rakowski, R. T., Franks, J., Woolliams, P., Weaver, P., \& Jones, B. J. (2014). The Effect of Substrate Geometry and Surface Orientation on the Film Structure of DLC Deposited using PECVD. Surface and Coatings Technology, 254, 73-78.

Pimpabute, N., Burinprakhon, T., \& Somkhunthot, W. (2011). Determination of optical constants and thickness of amorphous $\mathrm{GaP}$ thin film. Optica Applicata, 41(1), 257-268.

Podder, J., Rusop, M., Soga, T., \& Jimbo, T. (2005). Boron Doped Amorphous Carbon
Thin Films Grown by r.f. PECVD Under Different Partial Pressure. Diamond and Related Materials, 14(11-12), 17991804.

Raza, M. (2012). Synthesis of Hydrogenated Amorphous Carbon (a-C:H) Thin Films by HiPIMS-Based Processes. Linkopings University.

Robertson, J. (1995). Structural Models of a-C and a-C:H. Diamond and Related Materials, 4(4), 297-301.

Robertson, J. (2002). Diamond-Like Amorphous Carbon. Materials Science and Engineering: R: Reports, 37(4-6), 129281.

Robertson, John. (2011). Plasma Deposition of Diamond-Like Carbon. Japanese Journal of Applied Physics, 50, 01AF01.

Sze, S. M. (2002). Semiconductor devices, physics and technology (2nd ed). Wiley.

Tomasella, E., Meunier, C., \& Mikhailov, S. (2001). a-C:H Thin Films Deposited by Radio-Frequency Plasma: Influence of Gas Composition on Structure, Optical Properties and Stress Levels. Surface and Coatings Technology, 141(2-3), 286296.

Tomasella, E., Thomas, L., Dubois, M., \& Meunier, C. (2004). Structural and Mechanical Properties of a-C:H Thin Films Grown by RF-PECVD. Diamond and Related Materials, 13(9), 1618-1624.

Toro, R. G., Calandra, P., Cortese, B., de Caro, T., Brucale, M., Mezzi, A., Federici, F., \& Caschera, D. (2017). Argon and Hydrogen Plasma Influence on the Protective Properties of Diamond-Like Carbon Films as Barrier Coating. Surfaces and Interfaces, 6, 60-71.

Usman, I., \& Winata, T. (2009). Pengaruh Ketebalan Lapisan Aktif terhadap Karakteristik Sel Surya Berbasis a-Si: H yang Ditumbuhkan dengan Teknik HWCVHF-PECVD. Jurnal Matematika \& Sains, 13(4), 109-113.

Xiao, Y., Tan, X., Jiang, L., Xiao, T., Xiang, P., \& Yan, W. (2017). The Effect of Radio Frequency Power on the Structural and Optical Properties of a-C:H Films Prepared by PECVD. Journal of Materials Research, 32(07), 1231-1238. 